\title{
Periodismo y Literatura [presentación del monográfico]
}

\section{Journalism and Literature [monograph presentation]}

\section{Coordinadores científicos / Scientific coordinators}

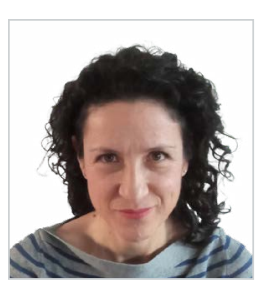

Sonia Parratt Fernández. Licenciada en Ciencias de la Información por la Universidad del País Vasco y Doctora Europea en Periodismo por la Universidade de Santiago de Compostela con una tesis doctoral sobre el reportaje en la prensa gallega. Es profesora titular en la Universidad Complutense de Madrid, donde imparte asignaturas de redacción y narrativa periodística en grado y máster. Directora del Grupo de Investigación en Redacción Periodística: Estilos, Narrativas y Géneros. Entre otras publicaciones, cuenta con las monografías "Introducción al reportaje: antecedentes, actualidad y perspectivas y Géneros periodísticos en prensa”, además de un capítulo en el libro International Literary Journalism: Historical Traditions and Transnational Influences. Ha hecho estancias de investigación sobre periodismo narrativo en las universidades de Columbia, Cornell y Harvard. Sus líneas de investigación son la redacción periodística, las relaciones entre el periodismo y literatura, el periodismo ambiental y el periodismo computacional. Cuenta con tres sexenios de investigación reconocidos por la CNEAI.

Bachelor's degree in Information Sciences from the University of the Basque Country, and a European PhD in Journalism from the University of Santiago de Compostela, where she has written a doctoral thesis on reportage in the Galician press. Professor Parratt Fernández is also a Lecturer at Complutense University of Madrid, where she teaches the subjects of journalistic writing and narratives in undergraduate and master's degree courses. She is also Director of the Research Group on Journalistic Writing: Styles, Narratives and Genres. Among other publications, she has published the monographs entitled "Introducción al reportaje: antecedentes, actualidad y perspectivas y géneros periodísticos en prensa", ("Introduction to feature reporting: background, current issues and perspectives, and journalistic genres in the press") as well as a chapter of the book entitled "International Literary Journalism: Historical Traditions and Transnational Influences". Professor Parratt Fernández has carried out research stays related to narrative journalism at Columbia, Cornell and Harvard Universities. Her research interests are in journalistic writing, the relationship between journalism and literature, as well as environmental and computational journalism. She has three six-year research terms recognised by the National Commission for the Evaluation of Research Activity (CNEAI).

Universidad Complutense de Madrid, España/Complutense University of Madrid, Spain

sfparratt@ccinf.ucm.es

ORCID: 0000-0001-8501-3115

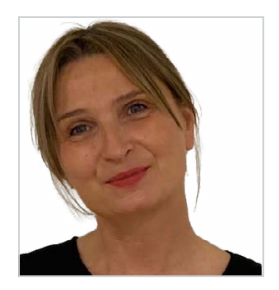

\begin{abstract}
Montse Mera Fernández. Doctora en Periodismo, en la actualidad es Profesora Contratada Doctora Interina en la Facultad de Ciencias de la Información de la Universidad Complutense de Madrid. Su experiencia docente se desarrolla en torno a asignaturas relacionadas con la redacción periodística. Sus líneas de investigación se centran en los géneros periodísticos para la información y la interpretación, la columna periodística, las fronteras entre el periodismo y la literatura y las relaciones entre cine y periodismo. Pertenece al Grupo Investigación en Redacción Periodística: Estilos, Narrativas y Géneros, evaluado favorablemente por la Agencia Española de Investigación y fue Visiting Fellow en el Real Colegio Complutense en Harvard (Universidad de Harvard), donde impartió la conferencia “The Magical Journalism of Álvaro Cunqueiro: A Tribute to his Centenary" ("El periodismo de Álvaro Cunqueiro. Un tributo en su centenario").

PhD in Journalism. She is currently an interim lecturer in the Faculty of Information Sciences at Complutense University of Madrid. The teaching experience of Professor Mera Fernández revolves around subjects related to journalistic writing. Her lines of research are focused on journalistic genres for information and interpretation, the newspaper column, the boundaries between journalism and literature, and the relationship between cinema and journalism as well. She belongs to the research group entitled Grupo de Investigación en Redacción Periodística: Estilos, Narrativas y Géneros, (Journalistic Writing Research Group: Styles, Narratives and Genres), which has received a favourable evaluation by the Spanish Research Agency, and she has also been a Visiting Fellow at the Real Colegio Complutense at Harvard University, where she delivered the Complutense University of Madrid lecture entitled "The Magical Journalism of Álvaro Cunqueiro: A Tribute to his Centennial".
\end{abstract}

Universidad Complutense de Madrid, España/Complutense University of Madrid, Spain mmera@ucm.es

ORCID: 0000-0003-4702-978

Cómo citar este artículo / How to cite this article:

Parratt Fernández, S.; Mera Fernández, M.; Meneses, J. P.; Vidal Castell, D. (2022). Periodismo y Literatura [presentación del monográfico] / Journalism and Literature [monograph presentation]. Doxa Comunicación, 34, pp. 247-254.

https://doi.org/10.31921/doxacom.n34a1595 


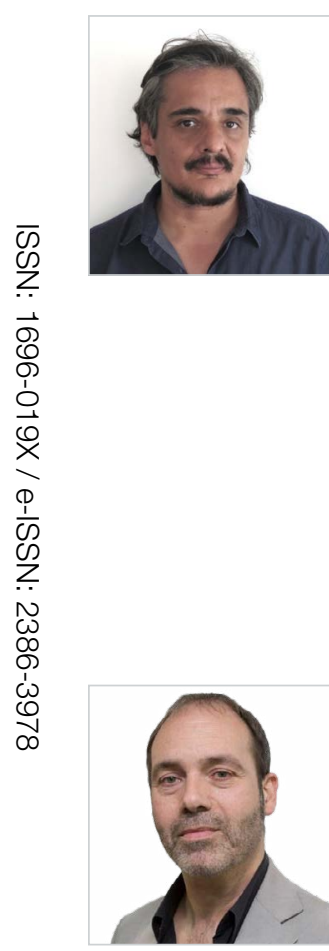

Juan Pablo Meneses. Profesor de Escritura de no ficción en la Escuela de Periodismo de la Universidad de Chile y director de la Universidad Portátil. Es Licenciado en Comunicación y periodista de la Universidad de Santiago de Chile, Máster en Comunicación y Educación de la Universidad Autónoma de Barcelona, y John S. Knight Journalism Fellow de la Universidad de Stanford, en California. Sus líneas de investigación se centran en crónica latinoamericana, periodismo y literatura, géneros literarios, y nuevas narrativas digitales. Ha publicado en revistas académicas de América Latina y Europa. En 2017 fue distinguido como Visiting Scholar de la Universidad de Nueva York (NYU). Ha dictado talleres de periodismo literario y ha sido cronista invitado en más de treinta universidades de América Latina, Estados Unidos y Europa. Ha escrito el prólogo en antologías de periodismo narrativo en Chile, Colombia, México y Perú. Como autor creativo ha publicado diez libros de no ficción y ha sido editado en más de 20 países y con traducciones a siete idiomas.

Professor of non-fiction writing in the School of Journalism at the University of Chile, and Director of Universidad de Portátil. He holds a bachelor's degree in Communication and Journalism from the University of Santiago de Chile, a master's degree in communication and Education from the Autonomous University of Barcelona, and is a John S. Knight Journalism Fellow at Stanford University in California. His lines of research focus on Latin American chronicles, journalism and literature, literary genres, and new digital narratives. He has published articles in academic journals in both Latin America and Europe. In 2017 he was honoured as a Visiting Scholar at New York University (NYU). Professor Meneses has taught literary journalism workshops and has been a guest journalist at more than thirty universities in Latin America, the United States and Europe. He has written the prologue to anthologies of narrative journalism in Chile, Colombia, Mexico, and Peru. As an author with a creative flair, he has written ten non-fiction books, and his works have been published in more than 20 countries and translated into seven languages. Universidad de Chile y Universidad Portátil, Chile/University of Chile and Portátil University juanmeneses@uchile.cl ORCID: 0000-0002-2845-7972

David Vidal Castell. Director del Departament de Mitjans, Comunicació i Cultura de la Universitat Autònoma de Barcelona, periodista y escritor, doctor en Comunicación (Alteridad y presencia, cum laude, 2001), es profesor titular de Periodismo Cultural, Escritura periodística y Periodismo Literario. Premio de narrativa de no ficción de la Diputación de Lleida por La fulla a punt de caure (La hoja que cae, 2007), premio de ensayo del Consell de l'Audiovisual de Catalunya por El malson de Chandos (La pesadilla de Chandos, 2005), y premio Gaudí al mejor documental por el guion de Petitet (2019). Ha sido coordinador del grado de Periodismo, vicedecano de la Facultat de Comunicació de la UAB y adjunto a la dirección del museo Arts Santa Mònica de Barcelona, donde creó un proyecto transmedia de arte y comunicación. Director del Màster de Periodismo Literario, Comunicación y Humanidades de la UAB, imparte clases de posgrado en otros tres másteres universitarios. Colabora en medios de prensa, radio y televisión como analista, y como crítico literario, en el diario Ara.

Director of the Department of Media, Communication and Culture at the Universitat Autònoma de Barcelona, as well as a journalist and writer. Professor Vidal Castell also holds a PhD in Communication for Alteridad y presencia (Alterity and presence), cum laude, 2001, and is a lecturer in Cultural Journalism, Journalistic Writing, and Literary Journalism. He has received the Nonfiction narrative award from the Lleida Provincial Council for La fulla a punt de caure (The Falling Leaf) 2007, an essay award from the Consell de l'Audiovisual de Catalunya (Catalan Audio-visual Council) for El Malson de Chandos (Chandos' Nightmare) 2005, and the Gaudi award for best documentary for the screenplay of Petitet (2019). He has been coordinator of the Journalism degree, Vice Dean of the Faculty of Communication at UAB and assistant director of the Arts Santa Mònica museum in Barcelona where he created a transmedia art and communication project. Professor Vidal Castell is also director of the master's degree in Literary Journalism, Communication and Humanities at UAB, and he has taught postgraduate classes in three other university master's degrees. He collaborates as an analyst in press, radio, and television, and as a literary critic for the newspaper Ara. Universidad Autónoma de Barcelona, España/Autonomous University of Barcelona, Spain

David.Vidal@uab.cat

ORCID: 000-0002-8178-6580

\section{Palabras clave:}

Periodismo; Literatura; periodismo literario; periodismo narrativo.
Keywords:

Journalism; literature; literary journalism; narrative journalism. 


\section{Presentación}

Si convenimos que en el principio fue la palabra, seguro que, en ese mismo inicio, fueron también las historias que nos hacen personas: solo los humanos, animal loquens, intentamos dar sentido a nuestras vidas y al mundo que compartimos con narraciones que fungen como praxis de dominación de la contingencia. En este continente simbólico de lo narrativo comparten territorio, desde hace ya unos siglos, el periodismo y la literatura, ambos atravesados estas últimas décadas por transformaciones y crisis que los han amenazado pero que también han intensificado su mutua promiscuidad. El periodismo literario ha vivido recientemente una verdadera explosión, tanto profesional (con una miríada de libros y nuevas publicaciones en papel o digitales) como académica, con numerosos y valiosos trabajos teóricos.

El periodismo, pues, una moderna actividad industrial vinculada al desarrollo tecnológico y a la capacidad narrativa y semiótica del ser humano, atraviesa desde finales del siglo XX un período de transformación tan profundo que ha acabado siendo una verdadera reconversión industrial, con un triple reto: el modelo de negocio, la transformación de los soportes y los medios, y la eclosión de los nuevos lenguajes. Entre dudas sobre lo que hoy es veraz (o al menos sobre lo que nos parece creíble), y con muchos reparos morales y profesionales sobre el papel del periodista y de la empresa periodística en este Occidente global desigual, asistimos al auge de un periodismo emocional, fundamentalmente entretenido, superficial y banal, que busca estrategias para sobrevivir a la competencia de la inmediatez del audiovisual expandido en las plataformas. El periodismo literario, en este contexto, actúa más como una subversión que como un mero embellecimiento, mira hacia lo emergente, hacia lo que es radicalmente otro; ha

\section{Presentation}

If we agree that in the beginning was the word, then surely at that same inception were also the stories that made us persons: only humans, animal loquens, attempt to make sense of our lives, as well as the world we share, through narratives that serve as a praxis for the domination of contingencies. In this symbolic world of narratives, journalism and literature have shared the same territory for centuries, both of which have been threatened by transformations and crises in recent decades, but which have also intensified their mutual heterogeneity. Literary journalism has recently experienced a genuinely strong upsurge, both professionally and academically, the former with a myriad of books and new publications, both in print and online, and the latter with numerous valuable, theoretical works.

Journalism as a modern large-scale industry, which is linked to technological development as well as to the narrative, semiotic capability of human beings, has been going through a period of transformation since the end of the 20th century. This transformation has been so profound that it has become a truly industrial conversion with three major challenges related to the following: the business model, the transformation of formats and media, and the emergence of new languages. There is no doubt about what is truthful today, or at least what seems believable, and with numerous moral and professional reservations about the role of the journalist and the journalistic business in this unequal, globalised Western world, we are witnessing the rise of a type of emotional journalism, essentially entertaining, superficial and banal, which is searching for strategies in order to survive the competition from the immediacy of the audio-visual media that has expanded on various platforms. 
sido así desde el auge de los muckrakers, la Generación Perdida o la extensión global del New Journalism y del periodismo narrativo latinoamericano.

El periodismo literario completa (y en parte, desmiente) la epistemología mecánica del periodismo objetivista, asume lo complejo del conocimiento y problematiza la noción de lo real para proyectar una mirada densa, más penetrante, que rompe la piel de lo superficial global. El periodismo literario no es el embellecimiento de la nota informativa, sino que fortalece y amplía el dispositivo cognitivo del periodismo, propone una mirada, un método y, finalmente, una estrategia formal, que utiliza los recursos de composición y estilo del realismo (mayoritariamente, aunque cada vez interesa más los aportes de la poesía, por ejemplo, a la escritura periodística). Es decir, ¿para qué querríamos belleza si nos están engañando? Sí, hay una diversidad de periodismos, y el periodismo literario es uno de ellos; y quizás todos nos son necesarios. Además, es muy pertinente observar que nuestra sociedad, como ha sido ampliamente descrito, atraviesa hoy una profunda crisis de alteridad. En la economía de las plataformas y la sociedad de la vigilancia, vivimos protegidos por filtros burbuja que dificultan la emergencia de lo otro. Esta no es una cuestión menor, puesto que el encuentro y la negociación con la alteridad ha conformado la civilización, las modernas prácticas políticas de las sociedades democráticas y el humanismo, tal como todos lo entendemos. Lo literario es, en este sentido, un ámbito de encuentro con la alteridad y con la esencial ambigüedad del ser. Y la manera como eso sucede en el periodismo literario de diversos autores y tradiciones, como Juan José Millás o Leila Guerriero, es, por ejemplo, lo que intentan desentrañar los artículos que constituyen este monográfico de Doxa Comunicación.
In this context, literary journalism operates as more of a subversion than a mere embellishment. It looks toward what is emerging, or to what is radically different. Moreover, this is the way things have been since the rise of the muckrakers, the Lost Generation, or the global spread of the New Journalism along with Latin American narrative journalism as well. Literary journalism complements and partially refutes the mechanical epistemology of objective journalism. It accepts the complexity of knowledge and questions the notion of what is real in order to project a deeper, more piercing gaze that breaks through what is comprehensively superficial. Literary journalism does not merely embellish news stories, but instead it strengthens and expands the cognitive mechanism of journalism, proposes a gaze, a method, and finally a formal strategy, which uses mostly the compositional and stylistic resources of realism, although the contributions of poetry to journalistic writing, to give one example, is becoming increasingly relevant. In other words, why do we want beauty if we are being deceived? While it is true that there is a diversity of journalism, and literary journalism is just one of them, perhaps all of them are necessary.

Moreover, it must be pointed out that society today is going through a profound crisis of otherness, as has been widely described. In the platform economy and surveillance society, we are protected by bubble filters that make it difficult for the other to emerge. This is no small matter, as the interaction and negotiation with otherness has shaped civilisation, modern political practice of democratic societies, and humanism as we all understand it. In this sense, what is considered literary is a sphere of encounter with otherness and with the essential ambiguity of being. Moreover, the way in which this happens in the literary journalistic work of various authors and traditions, such as Juan José Millás or Leila Guerriero, is an example what the articles that comprise this Doxa Comunicación monograph have attempted to unravel. 
El periodismo y la literatura comparten una larga y compleja historia académica. Tuvieron que pasar bastantes años hasta que la relación entre ambas fuera considerada objeto de estudio. Ya a finales del siglo diecinueve se practicaba en distintos países lo que más adelante se conocería como periodismo literario, y que con el paso del tiempo se ha resignificado con una amplia variedad de nombres distintos: periodismo narrativo, crónica periodística, no ficción creativa, crónica narrativa, periodismo lento, crónica literaria. Una serie de distintos nombres para enfocarse en lo mismo, dependiendo muchas veces del lugar geográfico donde se practica o si el estudio de esta relación viene desde el campo del Periodismo o del campo de la Literatura.

Los trabajos que publicamos a continuación se hacen cargo de esta larga tradición periodística literaria y la conectan con el presente de un género en constante evolución. En los últimos años, y para algunos inesperadamente, este género híbrido y clásico ha reflotado con fuerza, de manera innovadora, adaptándose a un escenario tecnológico de nuevas narrativas digitales. Esta nueva vida del periodismo literario está directamente relacionada con la fuerza, el valor y el interés de contar buenas historias. Especialmente en un mundo de hiperinformación que nos mantiene viviendo bajo una lluvia de noticias y una contaminación de datos.

Roberto Herrscher, de la Universidad Alberto Hurtado de Santiago de Chile, se centra en cómo se aborda desde el género de la crónica un tema que él considera fundamental en la literatura latinoamericana: la prostitución. Concretamente, su artículo revisa la obra periodística y literaria de varios autores para dibujar el lugar que ocupa dicho tema en la crónica del Cono Sur durante el siglo XX e intentar entender por qué los mismos escritores que trataron la prostitución en la ficción no mostraron interés por el asunto en sus crónicas. Como contra-
Journalism and literature share a long, complex, academic history. It took many years for the relationship between the two to be considered a subject of study.

As far back as the end of the nineteenth century, what would later become known as literary journalism was already being practised in various countries, and over time, it has been called a wide variety of names such as the following: narrative journalism, journalistic reporting, creative non-fiction, narrative reporting, slow journalism, and literary chronicle. There have been a series of different names for the same thing, often depending on the geographical location where it has been practiced, or whether the study of this relationship comes from the field of Journalism or the world of Literature.

The following works reflect this longstanding literary-journalistic tradition and connect it to the present in a constantly evolving genre. Unexpectedly for some, in recent years this hybrid/ classic categorisation has experienced a strong innovative revival, adapting itself to a technological scenario of new digital narratives. This new life of literary journalism is directly related to the strength, courage, and interest in telling good stories, especially in a world of hyper-information that keeps us living under a downpour of news and data pollution.

Roberto Herrscher of Universidad Alberto Hurtado in Santiago de Chile focuses on how the chronicle genre deals with a subject that he considers fundamental in Latin American literature: prostitution. Specifically, his article reviews the journalistic and literary works of several authors in order to describe the position occupied by this issue in the chronicles of the Southern Cone during the 20th century, and to try to understand why the same writers who dealt with prostitution in fiction did not show any interest in this topic in their reports. By contrast, the nonfiction story El camino de Buenos Aires by Albert Londres has 
punto, se analiza el relato de no ficción El camino de Buenos Aires, de Albert Londres, precursor en la región del tratamiento de este tema. Herrscher defiende que el hecho de que los periodistas narrativos latinoamericanos comenzaran a publicar crónicas sobre la prostitución a finales del siglo pasado, unido al enfoque con el que lo hacen, permite entender los cambios fundamentales que se han producido en la no ficción del continente.

Catalina Gayà, Cristina Garde y Laia Seró, de la Universitat Autònoma de Barcelona, se acercan al periodismo literario desde un enfoque interdisciplinar y reflexionan sobre las aportaciones de la etnografía a este periodismo. Proponen un periodismo basado en una mirada reflexiva como ejercicio participativo, dialógico y fruto de una escucha activa en el que los sujetos intentan interpretar, narrar y crear un mundo común. Lo hacen desde una concepción de la periodista como una persona que no es ni pasiva ni ajena a aquello que vive y narra. La propuesta de las autoras modifica las lógicas de la hipersimulación, puesto que permite a la comunidad apropiarse del aquí y ahora y abandonar el presente continuo. Defienden la función del periodismo literario como alternativa al metarrelato del capitalismo acelerado de la era digital y entienden que, en definitiva, la mirada reflexiva ofrece el marco epistemológico para ello.

Laura Ventura, de la Universidad Carlos III de Madrid, fusiona en su propuesta dos de los ejes temáticos que se proponían en la llamada a artículos del monográfico: la nueva crónica latinoamericana y las figuras representativas de la fusión periodismo-literatura. En este caso, la autora explora los perfiles de artistas creados por la narradora argentina Leila Guerriero, exponente de los autodenominados Nuevos Cronistas de Indias de América Latina. Examina cómo Guerriero plasma en sus textos la voz, las contradicciones y las obsesiones de been analysed as well. Londres was a pioneer in the region in addressing this topic. As Herrscher argues, the fact that Latin American narrative journalists began to publish stories about prostitution at the end of the last century, together with the approach they used, allows us to understand the fundamental changes that have taken place in non-fiction narratives on the continent.

Catalina Gayà, Cristina Garde, and Laia Seró of Universitat Autònoma de Barcelona examine literary journalism from an interdisciplinary approach and reflect on the contributions of ethnography for this kind of journalism. They propose a type of journalism based on a pensive perspective as a participatory, dialogical exercise and the result of active listening in which the participants try to interpret, narrate and create a common world. They carry out this task based on the concept of the journalist as a person who is neither passive nor detached from what he or she is experiencing and narrating. The proposal of the authors modifies the logic of hyper simulation, as it allows the community to appropriate the here and now and abandon the continuous present. They advocate literary journalism as an alternative to the meta-narrative offast-paced capitalism of the digital age, and they also believe that ultimately, a contemplative point of view provides the epistemological framework to take such an approach.

In another article, Laura Ventura of the Universidad Carlos III de Madrid combines two of the central themes proposed in the call for papers for this monograph: the new Latin American chronicle, and the leading figures of the journalism-literature combination. In this case, the author explores the profiles of artists created by the Argentinian narrator Leila Guerriero, an exponent of the self-styled New Chroniclers of the Indies of Latin America. She examines how Guerriero expresses in her writings the voices, contradictions, and obsessions of these 
estos realizadores hispanoamericanos a través de una mirada donde se advierte la subjetividad de la cronista, un elemento clave de su destreza narrativa al crear estos discursos biográficos. También explora cómo la narradora, a través de una aproximación hermenéutica, encuentra “tramas", en términos de Paul Ricoeur, en la interacción con sus entrevistados y en la interpretación de sus relatos y sus actos. Tramas que, acudiendo a elementos de diversos géneros, le permiten diseñar de forma original estos perfiles o versiones posibles de una vida que a menudo cuestionan las versiones oficiales.

La exploración de la identidad y de la alteridad es uno de los tópicos recurrentes en las aportaciones del periodismo literario. En un momento de especial preocupación por la polarización extrema de nuestras comunidades, y por la ausencia de empatía, Paula Fuentes propone un análisis cualitativo, textual y semiótico de la obra de no-ficción Hay algo que no es como me dicen: "el caso Nevenka Fernández contra la realidad", del prolífico escritor español Juan José Millás; en la obra, que describía un caso de acoso sexual que se convierte en polémica política, Millás cuestiona la construcción de la identidad y los factores que intervienen en ella. En la obra de Millás el periodismo, lejos de ser un oficio circunstancial, ocupa un lugar destacado, puesto que ha simultaneado la publicación de novelas con una extensa carrera en los medios de comunicación, y no solo como articulista de opinión sino, cosa menos frecuente, como cronista o entrevistador. Todos estos trabajos, asegura Fuentes en su artículo, presentan similitudes estructurales, lingüísticas y discursivas con su escritura ficción, aunque se centra específicamente en el estudio de la labor de construcción y exploración de la identidad de los personajes.

Al lanzar una publicación enfocada en el cruce del periodismo y la literatura, asumimos el desafío de entrar en una relación no exenta de polémicas, que han sido y son enriquecedoras
Latin American authors through a perspective that reveals the subjectivity of the chronicler, a key element of her narrative skill in creating these biographical discourses. She also explores how the narrator finds "plots", in the words of Paul Ricoeur, by taking a hermeneutical approach during the interaction with her interviewees and the interpretation of their stories and actions. As they resort to elements of diverse genres, these "plots" allow her to make an original creation of these profiles or possible versions of a life that often question the official versions.

The examination of identity and otherness is one of the recurrent themes in literary journalistic works. At a time of particular concern about the extreme polarisation of our communities and the absence of empathy, Paula Fuentes proposes a qualitative, textual, and semiotic analysis of the non-fiction work entitled, Hay algo que no es como me dicen: el caso Nevenka Fernández contra la realidad (There is something that is not the way I was told: the case of Nevenka Fernández against reality), by the prolific Spanish writer Juan José Millás. This work describes a case of sexual harassment that becomes a political controversy, as Millás questions the construction of identity and the factors involved therein.

In Millás's article, far from being a circumstantial profession, journalism occupies a lofty position, as he has combined the publication of novels with an extensive career in the media, not only as an opinion writer but also, less frequently, as a columnist and interviewer. In her article, Fuentes assures the reader that all of these works have structural, linguistic, and discursive similarities to Millás's fictional writing, although this author focuses specifically on the study of the work of construction and exploration of each character's identity.

In launching a publication focused on the convergence of journalism and literature, we have accepted the challenge of 
para ambas disciplinas y han dado lugar a una amplia diversidad de publicaciones. El objetivo de este monográfico es, precisamente, seguir actualizando y ampliando el conocimiento en un área que se nutre en la interacción permanente entre lo literario y lo periodístico. En ese sentido, esta publicación rescata investigaciones y artículos ya realizados, y deja un hito académico de referencia para publicaciones futuras que seguirán abordando el periodismo literario. entering into a relationship that is not without controversy, which has been and continues to be enriching for both disciplines, and has resulted in a wide variety of publications. The specific aim of this monograph is to continue updating and broadening knowledge in an area fuelled by the permanent interaction between the literary and journalistic realms.

In this regard, the publication of this monograph brings to light research and articles that have already been carried out, and leaves an academic milestone to be reached by future publications as they continue to address the topic of literary journalism. 